\title{
Prevalence of Sexual Harassment of Female Students of Tertiary Education in Taraba State, North East Nigeria: Implications for Counselling
}

\author{
Associate Prof. (Mrs.) Anna Onoyase ${ }^{1}$ \\ ${ }^{1}$ Department of Guidance and Counselling, Delta State University, P.M.B. 1 Abraka, Delta State, Nigeria. \\ Correspondence: Associate Prof. (Mrs.) Anna Onoyase, Department of Guidance and Counselling, Delta State \\ University, P.M.B. 1 Abraka, Delta State, Nigeria. E-mail: tinaonoyase@gmail.com
}

Received: December 28, 2018

Accepted: January 17, 2019

Online Published: January 21, 2019

doi:10.5430/ijhe.v8n1p77

URL: https://doi.org/10.5430/ijhe.v8n1p77

\begin{abstract}
The study was set out to investigate prevalence of sexual harassment of female students of tertiary education in Taraba State North East, Nigeria. One research question and one hypothesis were formulated to guide the study. The researcher used "Sexual Harassment of Female Students of Tertiary Education Questionnaire" (SHOFSOTEQ) to collect information for the investigation. The instrument was made up of 14 items and had a reliability coefficient of 0.85 . It had content validity and language appropriateness. The researcher used three research assistants to administer copies of the questionnaire on the respondents. The researcher chose 2.50 as a benchmark for either agreeing or disagreeing with each of the items. The One-Way Analysis of variance (ANOVA) was used to test the hypothesis at 0.05 level of significance. The study found out that: there is prevalence of sexual harassment of female students of tertiary education in Taraba State. Sexual harassment of female students' were carried out through inappropriate sexual comments, unwanted touching of female students' breasts, tapping of female students' buttocks and enticing of female students with high scores for sex amongst other. The result also revealed that there is no significant difference among the respondents in the universities, polytechnics and colleges of education on the prevalence of sexual harassment of female students. One of the recommendations is that authorities of tertiary educational institutions should put in place adequate measures to ensure that lecturers do not leak examination questions to students.
\end{abstract}

Keywords: prevalence, sexual harassment, and tertiary education

\section{Introduction}

In every open social organisation where there are boys, girls, men and women, there is likely to be interaction among them and such interaction could be positive or negative. Sexual harassment could therefore be a product of such negative interaction among boys, girls, men and women which may have far- reaching implications for individuals and the nation at large.

\section{Review of Related Literature}

Aluede (2000) defined sexual harassment as unwelcome, unsoliciated and unreciprocated sexual overtures from a person to elicit unwanted sexual relations from another person. On his part Akinade, (2005) defined sexual harassment as an unacceptable concept that involves an aggression against another person's body or psyche using sex as a weapon. It occurs in diverse places such as home, school and work place. He stressed that in view of the peculiar nature of lecturer - student relationship in tertiary education in Nigeria, some degree of sexual harassment may be exhibited.

Morley and Lussier, (2009) opined that, sexual harassment is a global problem, that has permeated the fabrics of higher education institutions and many work places where human beings interact. Sexual harassment in universities and other higher education institutions is not limited to Africa.

Ogunbameru (2006) noted that one of the factors responsible for sexual harassment in Nigerian tertiary education to include, indecent dressing pattern among female students. Ogunbameru further asserted that the female students dress in this manner to entice male lecturers. Abubakar Mohammed, Bala,Abdulkarim and Mohammed (2010) maintained that a factor speculated as favouring sexual assault in institutions of higher learningis indecent dressing 
by females which exposes thier sexual body parts (such as breast, navel and buttucks) through tight and transparent wears.

Gaba (2010), Imonikhe,Aluede and Idogho (2012) opined that sex in exchange for grades are found in tertiary institutions in Nigeria, where some male lecturersbelieve they could perpetuate this evil act as they wish.Adedokun (2005) noted that male academic staff were likely to be the main perpetrators. Continuing Adedokun stated that other perpetrators include non-academic male staff who oversee administration, registration, record keeping, examination and students' disciplinary committees.

Nwadiani (2018: 20) in the $12^{\text {th }}$ convocation ceremony lecture of the Delta State University, Abraka Nigeria, stated that sexual harassment of female students by lecturers have become a common practice in some universities in Nigeria. He cited the recent cases of ObafemiAwolowo University, Ile - Ife and Ambrose Ali University Ekpoma where two male professors demanded sex from two female students in exchange for marks. Nwadiani further noted that this new but dangerous development in Nigerian universities may have turned some of these institutions to prostitution/commercialization sex centres.

Odu and Babalola (2009) carried out a study of sexual harassment of female students in some tertiary institutions in Ekiti and Ondo States of Nigeria. One of the objectives of the investigation was to find out the existence of female sexual harassment in tertiary institutions. Secondly, to ascertain the category of persons responsible for sexual harassment. The population of the study according to the researchers were all the regular undergraduate females of tertiary institutions in Ekiti and Ondo States. Eight hundred female students were sampled for the study. The investigators used "Sexual Harassment Questionnaire" (SHQ) to elicit information from the respondents. The researchers used percentage and t-test to analyse the data collected from the fieldwork. One of the findings of the study was that sexual harassment of female students exist in the tertiary institutions of Ekiti and Ondo States. For instance, all the 800 female respondents attested to it. Another finding of the study showed that male lecturers in the four tertiary institutions use good grades as a baittoseduce female students into having sexual relationship with them. The finding equally revealed 83.3 percent of the university administrators in the four institutions used their position as a threat to have sexual relationship with the female students.

The finding also indicated that male academic staff were most sexual harassers with 96 percent, university administrators 3 percent while male non - academic staff, 1percent. Taiwo, Omole and Omole (2014) investigated sexual harassment and psychological consequence among students in higher education institutions in Osun State, Nigeria. Some of the objectives of the study were:

- To determine the nature and trend of sexual harassment among students in higher education institutions in Osun State, Nigeria.

- To ascertain the causes of sexual harassment as perceived by students in higher education institutions.

- To examine the psychological consequence of sexual harassment on the victims.

The population of the study was made up of students spread across the faculties of Arts, Education, Engineering, Clinical Sciences and Law. Others are Social sciences, Technology and Agriculture. 2,500 students were sampled from the population.A self-developed questionnaire with items on sexual harassment was used to obtain data for the study. The investigators used percentages to analyse the information collected from the fieldwork.Some of the findings indicated that, the most commonly occurring pattern of sexual harassment is from the male lecturers to female students, motivated through provocative dressing and sexual gestures, (98.8)percent. Other patterns are from female students to male lecturers, 62 percent, male students to female students, 79 percent and male lecturers to female lecturers, 55.6 percent. The pattern revealed that the female students were most exposed to sexual harassment.

\subsection{Operational Definition of Terms}

1) Tertiary Education:

In this study, tertiary education is defined as education received by students in universities, polytechnics and colleges of education.

2) Sexual Harassment:

Sexual harassment refers to sexual advances made by male lecturers and male non - academic staff to female students which could be verbal or non - verbal. 


\section{Statement of the Problem}

It appears to be a dramatic change to the researcher that the tertiary educational institution known to her as "Ivory Towers" of yester years, (that is, 1970s to 1980s) have suddenly become centres of sexual harassment in the 1990s till date. In the 1970s to 1980s, academic merit was the order of the day. But in the 1990s till date, academic merit of tertiary education in Nigeria seems to have been eroded. The question is: what is responsible for the erosion of the academic merit? The tertiary education institution instead of being centres of academic excellence, have degenerated to become centres of sexual harassment in Nigeria. This may be so because of the level of poverty Nigeria is currently undergoing. It may also be due to the aggressive way of dressing by some female students, and laziness on the part of some female students to study well for their examinations. The problem of this investigation put in a question form is: what is the prevalence of sexual harassment of female students of tertiary education of Taraba State, North East, Nigeria?

\section{Research Question}

One research question guided the study:

1. What is the prevalence of sexual harassment of female students in Universities, Polytechnics and Colleges of education in Taraba State, North East Nigeria?

\section{Hypothesis}

One hypothesis was formulated to guide the study:

There is no significant difference among respondents in the Universities,Polytechnics and Colleges of education in the prevalence of sexual harassment of female students in Taraba State, North East, Nigeria.

\section{Research Method and Procedure}

The research design adopted for this study is the Ex-post facto. Nnamdi (2002: 24) maintained that Ex-post Facto research is an empirical study in which the researcher does not in any way control or manipulate the independent variable because the situation for the study already exists or has already taken place.

The population of the study is made up of female students in the Universities, Polytechnics and Colleges of education in Taraba State, North- East, Nigeria. The instrument used for the collection of data is "Sexual Harassment of Female Students of Tertiary Education Questionnaire" (SHOFSOTEQ). It had 14 items of Strongly Agree (SA), 4 points, Agree (A) 3 points, Disagree (DA) 2 points and Strongly Disagree (SD) 1 point. The instrument has content validity as well as a reliability coefficient of 0.85 .The researcher collated the data collected from the field work and the mean and standard deviation analysis of the 14 items were done to provide answer to the research question and 2.50 was chosen as the benchmark for either agreeing or disagreeing with each of the 14 items. One way analysis of variance (ANOVA) was used to test the hypothesis at 0.05 level of significance. 


\section{Findings}

What is the prevalence of sexual harassment of female students in Universities, Polytechnics and Colleges of Education in Taraba State, North - East Nigeria?

Table 1.Mean and Standard Deviation of Prevalence of sexual harassment of female students in Universities, Polytechnics and Colleges of Education in Taraba State.

\begin{tabular}{|c|c|c|c|c|c|c|c|c|c|c|}
\hline \multirow[b]{2}{*}{$\mathbf{S} / \mathbf{N}$} & \multirow{2}{*}{$\begin{array}{l}\text { Items on sexual } \\
\text { harassment }\end{array}$} & \multicolumn{3}{|c|}{$\begin{array}{l}\text { Universities } \\
\mathrm{N}=\mathbf{3 1 1}\end{array}$} & \multicolumn{3}{|c|}{$\begin{array}{l}\text { Polytechnics } \\
\text { N }=163\end{array}$} & \multicolumn{3}{|c|}{$\begin{array}{l}\text { Colleges of Education } \\
\mathrm{N}=155\end{array}$} \\
\hline & & Mean & SD & Decision & Mean & SD & Decision & Mean & SD & Decision \\
\hline 1 & $\begin{array}{l}\text { Through } \\
\text { inappropriate } \\
\text { sexual comments }\end{array}$ & 3.05 & 0.89 & Agreed & 3.00 & 0.92 & Agreed & 3.02 & 0.89 & Agreed \\
\hline 2 & $\begin{array}{l}\text { Through } \\
\text { inappropriate } \\
\text { sexual looks }\end{array}$ & 3.17 & 0.84 & Agreed & 3.10 & 0.91 & Agreed & 3.05 & 0.92 & Agreed \\
\hline 3 & $\begin{array}{l}\text { Through unwanted } \\
\text { touching of female } \\
\text { students' breasts. }\end{array}$ & 3.03 & 0.98 & Agreed & 3.03 & 0.98 & Agreed & 2.99 & 1.02 & Agreed \\
\hline 4 & $\begin{array}{l}\text { By tapping female } \\
\text { students' buttocks. }\end{array}$ & 2.91 & 0.98 & Agreed & 2.79 & 1.07 & Agreed & 2.91 & 1.03 & Agreed \\
\hline 5 & $\begin{array}{l}\text { Through threat of } \\
\text { failure in } \\
\text { examination if sex } \\
\text { is refused }\end{array}$ & 3.32 & 0.91 & Agreed & 3.36 & 0.96 & Agreed & 3.20 & 0.97 & Agreed \\
\hline 6 & $\begin{array}{l}\text { Leaking of } \\
\text { examination } \\
\text { questions to } \\
\text { female students } \\
\text { in exchange for } \\
\text { sex }\end{array}$ & 3.07 & 0.93 & Agreed & 2.97 & 0.98 & Agreed & 2.96 & 0.97 & Agreed \\
\hline 7 & $\begin{array}{l}\text { Enticing female } \\
\text { students with high } \\
\text { scores for sex }\end{array}$ & 3.31 & 0.79 & Agreed & 3.08 & 1.02 & Agreed & 3.07 & 1.01 & Agreed \\
\hline 8 & $\begin{array}{l}\text { By sending nude } \\
\text { photographs to } \\
\text { female students }\end{array}$ & 2.79 & 0.95 & Agreed & 2.68 & 0.87 & Agreed & 2.70 & 0.96 & Agreed \\
\hline 9 & $\begin{array}{l}\text { By sending nude } \\
\text { photographs to } \\
\text { female students. }\end{array}$ & 2.65 & 1.00 & Agreed & 2.56 & 0.94 & Agreed & 2.59 & 0.94 & Agreed \\
\hline 10 & $\begin{array}{l}\text { By refusing to } \\
\text { authenticate some } \\
\text { female students' } \\
\text { school fees } \\
\text { receipts if sex is } \\
\text { refused. }\end{array}$ & 2.54 & 1.05 & Agreed & 2.46 & 1.07 & 冫 & 2.55 & 0.97 & Agreed \\
\hline 11 & $\begin{array}{l}\text { Through threats of } \\
\text { failure if female } \\
\text { students } \\
\text { persistently reject } \\
\text { invitation to social } \\
\text { activities }\end{array}$ & 2.78 & 1.04 & Agreed & 2.66 & 0.98 & Agreed & 2.83 & 1.02 & Agreed \\
\hline
\end{tabular}




$12 \begin{aligned} & \text { By influence } \\ & \text { disciplinary cases } \\ & \text { in favour of } \\ & \text { female students in } \\ & \text { return for sex } \\ & 13\end{aligned}$

Table 1 revealed the prevalence of sexual harassment of female students in Universities, Polytechnics and colleges of Education, with a grand mean of 2.94 for universities, 2.87 for polytechnics and 2.89 for Colleges of Education. The table indicated that female universities' students agreed to items $1-14$ with a mean ranged of $2.52-3.32$ which were within the criterion level of 2.50 and above and were accepted. This implied that there exist prevalence of sexual harassment of female students in universities. The female polytechnics' students agreed to items $1,2,3,4,5,6,7,8,9,11,12$ and 13 with a mean ranged of $2.56-3.36$ which were within the criterionlevel of 2.50 and above and were accepted.While items 10 and 13 with a mean ranged of $2.46-2.47$, were below the criterion level of 2.50 and were rejected. Moreso, female colleges of Education Students agreed to items 1,2,3,4,5,6,7,8,9,10,11,12 and 14 with a mean ranged of $2.55-3.20$ which were with the criterion level of 2.50 and above as acceptance while item 13 with a mean of 2.48 was below the criterion level of 2.50 was rejected.

\section{Hypothesis}

There is no significant difference among respondents in the Universities, Polytechnics and Colleges of education on the prevalence of sexual harassment of female students.

Table 2.One way Analysis of Variance (ANOVA) among respondents in the universities, polytechnics and colleges of Education on the prevalence of sexual harassment of female students

\begin{tabular}{llllll}
\hline Source of variation & Sum of squares & df & Mean square & F & Sig \\
\hline Between groups & 141.430 & 2 & 70.715 & 1.699 & 0.184 \\
Within groups & 26060.881 & 626 & 41.631 & & \\
Total & 26202.312 & 628 & & & \\
\hline
\end{tabular}

Table 2, showed that the computed F - value of 1.699 and a $\mathrm{p}$ - value of 0.184 . Testing the hypothesis at an alpha level of 0.05 , the $p-$ value of 0.184 was greater than the alpha level of 0.05 . Therefore, the null hypothesis which states that there is no significant difference among respondents in the universities, polytechnics and colleges of Education on the prevalence of sexual harassment of female students is accepted. Consequently, there is no significant difference among respondents in the universities, polytechnics and colleges of education on the prevalence of sexual harassment of female students. This indicates that there is sexual harassment of female students in tertiary education institutions.

\section{Discussion}

One of the findings of this investigation revealed that there is prevalence of sexual harassment of female students in universities, polytechnics and colleges of education in Taraba State. This implies that there is a high rate of incidences of sexual harassment in tertiary education institutions in Taraba State. This may be so because victims do not have the courage to report such cases to appropriate Authorities.The finding lends credence to that of Odu and Babalola (2009) whichrevealed that sexual harassment of female students exist in the tertiary institutions of Ekiti and Ondo States in Nigeria. For instance, all the 800 female respondents attested to it. The present study indicated in items seven (7) that female students in universities, polytechnics and colleges of education were enticed with high grades for sex. This finding is in consonance with that of Odu and Babalola who found out that male lecturers in the 
four tertiary institutions of Ekiti and Ondo States used good grades as a bait to seduce female students into having sexual relationship with them.The finding also supports the views of Gaba (2010) Imonikhe, Aluede and Idogho (2012) opined that sex in exchange for grades are found in tertiary institutions of Nigeria. They stressed that male lecturers believe they could perpetuate this evil act as wish.This result corroborates that of Taiwo, Omole and Omole (2014) which indicated that found out that female students in higher education institutions in Osun State, Nigeria, were exposed to sexual harassment. This study also revealed that in items twelve (12), thirteen (13) and fourteen (14) that male non - academic staff in the universities, polytechnics and colleges of education use their positions to influence disciplinary cases in favour of some female students in return for sex, through promise of bed spaces for some female students in return for sex and by promise of admission for some female students with scores below cut-off marks in exchange for sex.

Thisfindings is in consonance with that of Odu and Bablola (2009) whichrevealed that 83.3 percent of the university administrators in the four institutions use their positions as threat to have sexual relationship with female students. The finding also agrees with Adedokun (2005) who observed that non - academic male staff who oversee administration, registration, record keeping, examination and students' disciplinary committees are perpetrators of female sexual harassment.

Another finding of the study shows that there is no significant difference among the respondents in the Universities, Polytechnics and Colleges of Education. This indicates that the institution to which a respondent belongs does not matter, all the respondents are of the view that there is prevalence of sexual harassment of females in higher education institutions in Taraba State North East, Nigeria. This position is further buttressed by the fact that the grand mean of 2.94, 2.87 and 2.89 for universities, polytechnics and Colleges of Education respectively are above the bench mark of 2.50 for accepting that there is prevalence of sexual harassment of females.

\section{Conclusion}

The study investigated prevalence of sexual harassment of female students in higher education institution in Taraba State, North East Nigeria: Implications for counselling. The conclusion that can be drawn as a result of the findings is that sexual harassment of female students exists and is perpetrated by male lecturers and non-academic male staff against the female students. Some of the male lecturers use various methods to get some female students sexually harassed such as failure in examination if sex is refused. Some non - academic staff get some female students sexually harassed by influencing disciplinary cases in favour of some female students in return for sex.

\section{Recommendations}

In view of the findings and conclusion reached the following recommendations are proposed:

1. School authorities should put in place modalities for vetting of students' examination booklets after lecturers have marked, to ensure the credibility of scores awarded to students.

2. Authorities of tertiary educational institution should devise adequate measure to ensure that lecturers do not leak examination questions to female students as a means of sexually harassing them.

3. Students disciplinary committees should be made up of men and women with proven integrity so that cases of students'misbehavour are not manipulated in exchange for sex.

4. The Authority of the Universities, Polytechnics and Colleges of Education should ensure that only students who got up to cut-off scores are admitted.

5. Authorities of tertiary education should ensure that bed spaces in various institutions are given out on the basis of "first come, first serve" policy and not on the basis of exchange for sex.

6. Behaviours indicative of sexual harassment should be entrenched into the conditions of service of staff of tertiary education as well as faculty and students' handbooks to create the needed awareness.

7. School authorities should encourage team teaching among lecturers to act as a check against female sexual harassment. 


\section{Counselling Implications}

The following are the implications of the study:

1. Professional counsellors are needed in tertiary educational institutions to organise seminars on an annual basis for students and staff (academic and non - academic) on the behaviours that constitute sexual harassment.

2. Guidance counsellors should intimate female students on the physical and psychological effects of sexual harassment on victims.

3. Counsellors are to train female students to build up confidence in themselves and their abilities, develop their potentialities to the fullest and contribute meaningful to national growth.

\section{References}

Aluede, O. O. (2009). Sexaul harassment of women employed in a Nigerian university. implications for Guidance Counselling, 15(2), $27-32$.

Abubakar, A. K., Mohammed, B.K., Bala, M. A., Abdulkarim, G. M. \& Mohammed, B. (2010). Sexual assault against female Nigerian Students. African Journal of Reproductive Health, 14(3), 189-193.

Adedokun, O. (2005). Sexual harassment in Nigerian Educational Settings: Preliminary note from a qualitative assessment of Lagos State University. Sexuality in African Magazine, 2(4), 1-4.

Akinade, E. A. (2005). Dictionary of Guidance and Counselling. (Counselling Psychology, Ibadan: Olu - Akin Publishers, 171.

Gaba, S. (2010). Sexual harassment in Nigeria Tertiary Institutions. The Psychologist, 5(8), 319 - 321.

Imonikhe, J., Aluede, V. O. \& Idogho, P. (2012). A survey of teacher and Students perception of Sexual harassment in tertiary institutions of Edo State Nigeria. Journal of Asian Social Science, 8(1), 268 - 273.

Moley, L. \& Lussier, K. (2009). Sex grades and power gender violence in Africa higher education. Cambridge Journal of Education, 41(1), 101 - 115.

Ogunbamere, A. O. (2006). Sexual harassment in Nigeria tertiary institutions, Ibadan: Spectrum books Ltd.

Odu, B. K. \& Babalola, A. A. (2009). Sexual harassment of female students in some tertiary institutions in Ekiti and Ondo State. TheCounsellors, 26(2), 121- 132.

Taiwo, M. O.; Omole, O. C. \& Omole, O. E. (2014). Sexual harassment and psychological consequence among students in higher education institutions in Osun State Nigeria. International Journal of Applied Psychological, $4(1), 13-18$.

Nnamdi, A. (2002). Research methodology in the behavioural sciences Lagos: Longman Nigeria Ltd.

Nwadiani, M. (2018). University Education Beyond certification in Nigeria: Threats and Leadership Imperative, $12^{\text {th }}$ convocation ceremony lecture of the Delta State University, Abraka, Nigeria. 